\title{
Significance of Erythrocyte Sodium Flux in the Pathophysiology and Genetic Expression of Hereditary Spherocytosis
}

\author{
Alvin Zipursky ${ }^{[18]}$ AND Lyonel G. Istraeis \\ Department of Pediatrics, McMaster University, Iamilton, Ontario; and the Department of Medicine, University of Manitoba, \\ Winnipeg, Manitoba, Canada
}

\begin{abstract}
Extract
Erythrocyte sodium transport was studied in five families of patients with hereditary spherocytosis (HS). Values for ouabain-insensitive sodium efflux in the group with HS $($ mean $=19.9 \%$ of cellular sodium-22/hr, $\mathrm{sD}= \pm 2.7)$ werc significantly greater $(P<0.001)$ than those found in the normal group (mean $=13.8 \%$, sD $= \pm 2.7)$. No clinical evidence of HS was found in the parents; however, 4 of the 10 parents had ouabain-insensitive erythrocyte sodium-22 efflux rates in the HS range in comparison to 3 of 30 control subjects, a statistically significant difference $\left(x^{2}=4.67 ; P<0.05\right)$.

\section{Speculation}

The finding of high erythrocyte, ouabain-insensitive sodium eflux rates in hematologically normal parents of patients with hereditary spherocytosis (HS) suggests that the shortened erythrocyte life span in patients with HS is unrelated to the increased erythrocyte sodium permeability and that the gene for HS may manifest itself merely as an increase in erythrocyte sodium permeability with no other hematological abnormality.
\end{abstract}

\section{Introduction}

In hereditary spherocytosis (HS) the crythrocyte membranc is abnormally permeable to sodium $[1,4,6,8]$; this defect has been suggested as being responsible for the shortened erythrocyte life span in HS [6]. In this study, we present evidence contrary to this theory by describing several subjects with little or no evidence of IIS in whom erythrocyte sodium tramsport is identical to that found in this condition. Furthermore, our data suggest that the gene for HS may manifest itself merely as an increase in sodium permeability with no other hematologic abnormality.

\section{Methods}

Routine hematologic techniques were carried out as described by Dacie [3, 14]. Chromium-51 survival studies were performed by standard techniques [9].

Studies of sodium-22 eflux and sodium concentration were performed by methods described in the litera. ture $[8,10]$ and involved preincubation ( $1 \mathrm{hr}$ at $37^{\circ}$ ) of washed erythrocytes in a Tris- $\mathrm{KCl}$ buffer $(150 \mathrm{~mm}$ $\mathrm{KCl}, 10 \mathrm{~mm}$ Tris, $10 \mathrm{mM}$ glucose, $\mathrm{pH}$ 7.45) containing sodium-22 chloride to load the cells. These cells were then washed and resuspended in buffer $(10 \mathrm{~mm}$ glucose, $135 \mathrm{~mm} \mathrm{NaCl}, 15 \mathrm{~mm} \mathrm{KCl}, 10 \mathrm{~mm}$ Tris, $\mathrm{pH} 7.45$ ) with 
or without added ouabain $(0.05 \mathrm{~mm})$. Sodium-22 efflux from these suspensions was determined and ouabainsensitive and ouabain-insensitive efflux was calculated. The average difference in day-to-day analysis of $13 \mathrm{con}$ trol and test subjects was $0.85 \%$ (sD $\pm 0.85 \%$ ), expressed as percentage of cellular sodium-22/hr.

Following the initial two buffer washes, sodium concentrations were determined on erythrocytes by direct analysis of packed red cell columns, as described by Zipursky et al. [13]. Since the cells had been washed and resuspended in Tris- $\mathrm{KCl}$ buffer, no correction was made for trapped fluids.

\section{Results}

Five families formed the experimental unit for these studies. Hereditary spherocytosis had been diagnosed in one child from each of four families and in two children in the fifth family.

Diagnostic features in the affected children included anemia, reticulocytosis, abnormal osmotic fragility and autohemolysis, microspherocytosis, and cure of the hemolytic process by splenectomy.

The families were unusual in that no clinical evidence of HS was found in the parents; normal results were found in each case for hemoglobin concentration, reticulocyte count, serum bilirubin, incubated and nonincubated osmotic fragility, autohemolysis, and morphology of the red blood cells.

Rate constants for ouabain-insensitive sodium-22 efflux for erythrocytes from normal subjects and those with HS are shown in Figure 1.

The values found in the group with HS (mean = $19.9 \%$ of cellular sodium-22/hr, sv $= \pm 2.7$ ) were significantly greater $(P<0.001)$ than those observed in the normal group (mean $=13.8$, sD $= \pm 2.7$ ). It should be noted, however, that three subjects in the normal group had rate constant values in the HS range.

Studies of ouabain-insensitive sodium-22 efflux in 4 of the 10 parents were in the HS range (Fig. 1). The values in these parents, expressed as $22 \mathrm{Na}$ efflux/hr, were: $M r . J: 20.3,19.9 ; M r . M: 17.9,18.3 ; M r s .13: 20.3$, 20.8, 20.8; and $M r . B: 18.0$. The last two represent the parents of one family. In two families, $K$ and $F$, erythrocyte sodium efflux was normal in both parents. Thus, 4 of 10 parents had rate constants in the HS range in comparison to 3 of 30 control suljects, a statistically significant difference $\left(x^{2}=4.67 ; P<0.05\right)$.

Three parents were studied further to determine whether any other evidence of HS could be detected.

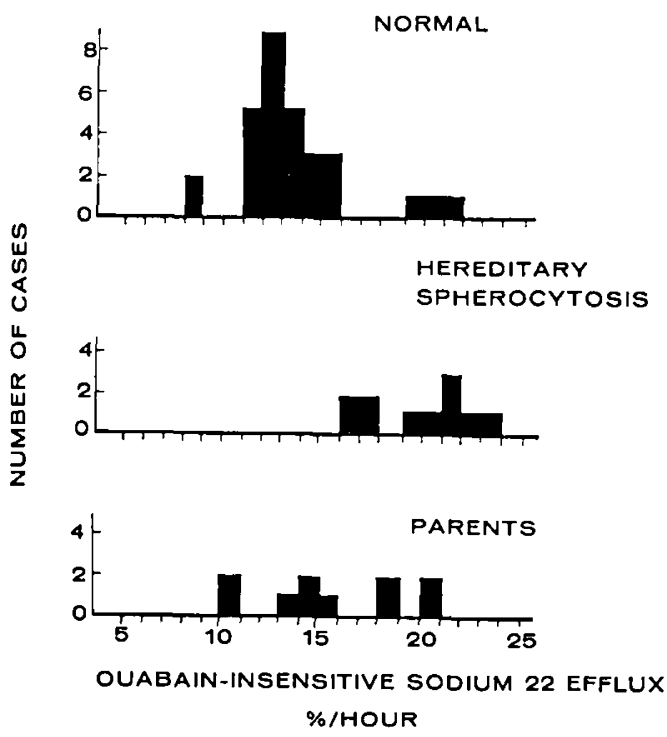

Fig. 1. Erythrocyte ouabain-insensitive sodium-22 cflux valucs in normals and patients with hereditary spherocytosis (in remission, postsplenectomy). The spherocytic group included four children from the five families studied, as well as seven patients with a classical family history of hereditary spherocytosis. Hematologically normal parents of the patients with hereditary sphero. cytosis in the present study are also shown.

As noted earlier, hematologic measurements were normal, and chromium-51 erythrocyte survivals were the following (50\% survival time): $M r . J: 26$ days; $M r . M$ : 23 days; and Mrs. B: 25.5 days. These survivals are low-normal or slightly below the normal range of 25-40 days [9].

Ouabain-insensitive rates of sodium efflux were determined on two of these subjects, $M r . M$ and $M r s . B$, and the results are shown in Figure 2. These data are divided on the basis of sex because of previous observations which show that erythrocyte sodium values in men are significantly higher than in women [7]. Our data clo inclicate that ouabain-insensitive sodium efflux rates in men (mean $=1.13 \mathrm{mEq}$ sodium $/$ liter cells $/ \mathrm{hr}$; SD \pm 0.15$)$ are significantly greater $(P<0.001)$ than in women (mean $=0.82 \mathrm{mEq}$ sodium/liter cells $/ \mathrm{hr}$; $\mathrm{sD}$ \pm 0.18 ). These data appear to reflect the higher sodium concentrations in men (mean $=8.2 \mathrm{mEq} /$ liter cells; $\mathrm{sD}$ $\pm 1.6)$, than in women (mean $=6.3 \mathrm{mEq} /$ liter $\mathrm{sD} \pm$ $0.8)$. The difference between these two concentrations is also significant $(P<0.001)$.

Sodium values in the present study were lower than those in fresh, unwashed erythrocytes [8]. Presumably, the washes in sodium-free buffer lower the sodium content.

The ouabain-insensitive efflux rates for five males 

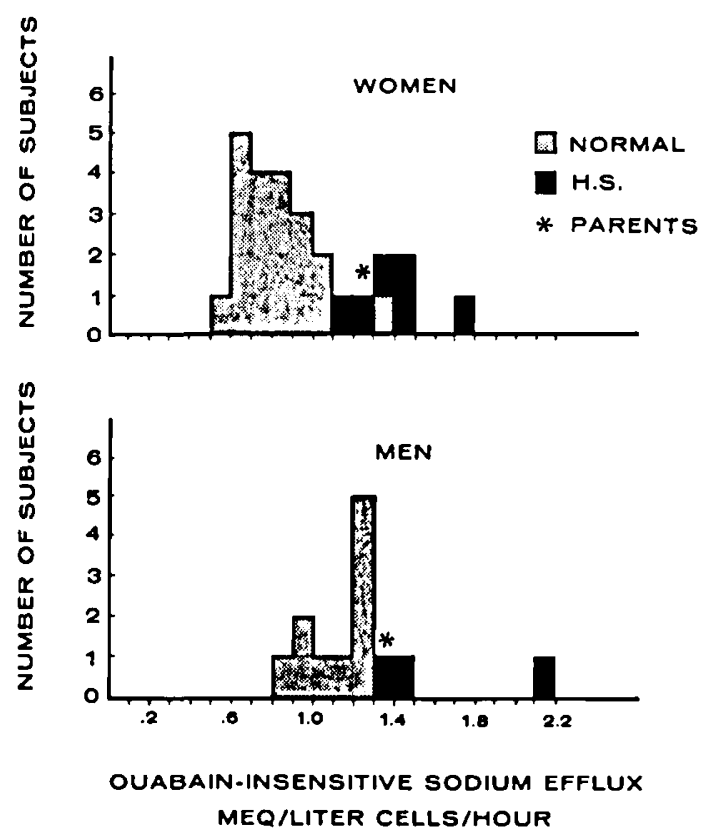

Fig. 2. Frythrocyte oubain-insensitive solium eflux rates in nomals, patients with hereditary spherocytosis (in remission, postsplenectomy), and two hematologically normal parents. The values for the parents, Mis. $B$ and $M I r$. $M$, are shown as asterisks on the graph for women and men, respectively.

with $\mathrm{HS}$ were $1.49 \mathrm{mE} /$ liter cells/hr (sD \pm 0.36 ), values significantly greater than those for normal males, cited above $(P<0.05)$. Similarly, sodium efllux rates for six females were $1.10 \mathrm{mEq} /$ liter cells/hr (SD \pm $0.12)$, values significantly greater than those for normal females $(P<0.001)$. The sodium efflux rates in $M r . M$ were 1.38 and in Mrs. B, 1.26, values clearly in the HS range.

Erythrocyte sodium concentrations and ouabain-sensitive efflux, sodium-potassium pump, however, were normal in all 10 parents.

\section{Discussion}

The data in Figures 1 and 2 indicate that ouabain-insensitive sodium transport in patients with HS is significantly greater than in normal subjects $(P<0.001)$. Ouabain-insensitive sodium efllux includes the movement of sodium both by diffusion and by a recently described active process, "pump II" [5]. Our clata do not inclicate which of these components is increased in HS. This matter is dealt with in greater detail elsewhere [8]. Our findings, however, are consistent with previous observations $[1,4,6]$ which suggest that soclium permeability is increased in the erythrocyte mem. branc in patients with $\mathrm{HS}$.
Certain normal subjects, as well as several parents of patients with IS, showed ouabain-insensitive sodium efflux in the IS range, and yet there was little or no evidence of a hemolytic process. These observations on normal subjects are consistent with the studies of Wiley [11], who reported recently that there was no correlation between sodium influx (presumably measuring permeability) and erythrocyte survival in patients with HS. These findings are inconsistent with the thesis that the increased sodium permeability of erythrocytes of patients with HS plays a central role in the pathogenesis of the hemolytic anemia in this disease [6]. It is more likely the case that the increased sodium permeability characteristic of HS merely reflects an erythrocyte membrane defect in this particular clisease.

Classically, IIS is inherited as a Mendelian dominant. In the five families described in this report, there was no evidence of HS in any of the parents. These families are similar to those described by Dacie [2] and Young [12]. In one family described by Young [12]. one parent had abnormal crythrocyte morphology and osmotic fragility with no evidence of disease.

None of the parents of the five families in this study had abnormal erythrocyte osmotic fragility. Of considcrable interest, however, is the fact that 4 of the 10 parents had efflux rates in the IIS range, as opposed to a significantly lower incidence $(3 / 30)$ in the control group $(P<0.05)$. Nlthough this is a small series, and therefore the results must be interpreted with caution, this observation suggests that some of these parents carried the gene for HS which manifested in them only as an increase in erythrocyte ouabain-insensitive sodium efflux, or membrane permeability. Finally, it should be noted that in two of the families, $K$ and $r$, membrane permeability was normal in both parents; in them there was no demonstrable expression of the gene for HS. In one of these families, $F$, two of four children had HS, suggesting that the disease, in these children, did not represent a mutation but had been transmitted from one or both of the unaffected parents.

We have interpreted these findings to mean that in addition to classical cases with hemolytic disease, the gene for HS may express itself either as an abnormality in erythrocyte morphology with a normal erythrocyte life span or as an increase in membrane permeability with normal erythrocyte morphology and life span. In some instances no hematologic abnormalities can be found in presumed carriers of the HS gene.

The reasons for these differences in genetic expres- 
sion are unknown and will remain so until we understand, more fully, the erythrocyte abnormality in HS.

\section{Summary}

In hereditary spherocytosis (HS), erythrocyte ouabaininsensitive sodium efflux is greater than normal. In the present study, however, normal subjects are described in whom erythrocyte sodium efflux is in the HS range. These findings contradict the hypothesis that an increase in erythrocyte sodium permeability is responsible for the shortened erythrocyte life span in HS. The finding in the present study of a greater incidence of high efflux rates in hematologically normal parents of patients with HS suggests that the gene for HS may be expressed as an abnormality in erythrocyte sodium efflux with little or no evidence of hematologic disease.

\section{References and Notes}

1. Berti.f, J. E.: Sodium transport across the surface membrane of red blood cells in herelitary spherocytosis. J. Clin. Invest., 36: $816(1957)$.

2. DAcie, J. V.: The Hacmolytic Anemias, Part I. The Congenital Anaemias. (Grune and Stratton, New York, 1960).

3. DACIf, J. V., AND LEw's, S. M.: Practical Hematology, ed. 3 (Churchill, London, 1963).

4. Harris, E. J., and Prankler, T. A. J.: The rate of sodium extrusion from human erythrocytes. J. Physiol., 121: 470 (19:3).

5. Hoffaran, J. F., and Krfernow, F. M.: The characterization of new energy dependent cation transport processes in red blood cells. Ann. N.Y. Acad. Sci, 137: 566 (1966).
6. JAcon, H. S., and Jande, J. H.: Increased cell membrame permeability in the pathogenesis of hereditary spherocytosis. J. Clin. Invest., 43: 1704 (1964).

7. Keitri., H. G., Berian, H., Jonfe, H., ANd Maclacilitan, D.: The chemical composition of normal human red blood cells including varialsility among centrifuged cells. Blood, 10:370 (1955).

8. Mayman, D., Iskafis, L. G., and Zipursky, A.: Hereditary spherocytosis: The metabolism of erythrocytes in the peripheral blood and in the splenic pulp. To be published.

9. Owen, C. A., Jk.: Diagnostic Radioisotopes, p. 183 (Thomas, Springficld, Ill., 1959).

10. Pfiters, J. C., Rowland, M., Zipursky, A., Ano Israels, L. G.: Erythrocyte sodium transport in hereditary elliptocytosis. Can. J. Physiol. Pharmacol., 44: 817 (1966).

11. WuseY, J. S.: Red cell survival studies in hereditary spherocytosis. J. Clin. Invest., 49: 666 (1970).

19. Younc, L. E.: Obscrvations on inheritance and heterogeneity of chronic spherocytosis. Trans. Ass. Amer. Physicians, 68: 141 (1955).

13. Zipursky, A., LaRuf, T., AND IsRaels, L. G.: The in vitro metabolism of crythrocytes from newborn infants. Can. J. Biochcm. Plyysiol., 38: 727 (1960).

14. Informed consent was obtained for all studies in accordance with the provisions set forth in the Declaration of Helsinki.

15. We should like to acknowledge the skilled technical assistance of Miss Diane Blakely, Miss Alice Vust, and Mrs. M. Stephens, and the clerical assistance of Mrs. Alma Fraser.

16. Presented in part at the Annual Mecting of the Society for Pediatric Research, Atlantic City, N.J., May, 1970.

17. Supported by a grant from the Medical Research Council of Canada.

18. Requests for reprints should be addressed to: Atvin 7.IPURskY, M.D., Department of Pediatrics, MrMaster University, Hamilton, Ontario, Canada.

19. Accepted for publication January 7,1971 . 